\title{
Capture of Tritium Released from Cladding in the Zirconium Recycle Process
}

\section{Fuel Cycle Technology}

Prepared for U.S. Department of Energy Materials Recovery and Waste Form Development Campaign B. B. Spencer T. B. Walker S. H. Bruffey G. D. DelCul

September 2016 FCRD-MRWFD-2016-000016 (rev 1) FCRD-MRWFD-2016-000297 (rev 1) ORNL/TM-2016/444 (rev 1) ORNL/TM-2016/531 (rev 1) 



\section{DISCLAIMER}

This information was prepared as an account of work sponsored by an agency of the U.S. Government. Neither the U.S. Government nor any agency thereof, nor any of their employees, makes any warranty, expressed or implied, or assumes any legal liability or responsibility for the accuracy, completeness, or usefulness, of any information, apparatus, product, or process disclosed, or represents that its use would not infringe privately owned rights. References herein to any specific commercial product, process, or service by trade name, trade mark, manufacturer, or otherwise, does not necessarily constitute or imply its endorsement, recommendation, or favoring by the U.S. Government or any agency thereof. The views and opinions of authors expressed herein do not necessarily state or reflect those of the U.S. Government or any agency thereof. 



\section{SUMMARY}

This report is issued as the first revision to FCRD-MRWFD-2016-000297.

Zirconium may be recovered from the Zircaloy ${ }^{\circledR}$ cladding of used nuclear fuel (UNF) for recycle or to reduce the quantities of high-level waste destined for a geologic repository. Recovery of zirconium using a chlorination process is currently under development at the Oak Ridge National Laboratory. The approach is to treat the cladding with chlorine gas to convert the zirconium in the alloy ( $\sim 98 \mathrm{wt} \%$ of the alloy mass) to zirconium tetrachloride.

A significant fraction of the tritium (0-96\%) produced in nuclear fuel during irradiation may be found in zirconium-based cladding and could be released from the cladding when the solid matrix is destroyed by the chlorination reaction. To prevent uncontrolled release of radioactive tritium to other parts of the plant or to the environment, a method to recover the tritium may be required.

The focus of this effort was to (1) identify potential methods for the recovery of tritium from the off-gas of the zirconium recycle process, (2) perform scoping tests on selected recovery methods using nonradioactive gas simulants, and (3) select a process design appropriate for testing on radioactive gas streams generated by the engineering-scale zirconium recycle demonstrations on radioactive used cladding.

It was determined that the off-gas from the zirconium recycle process is most likely to contain tritium as $\mathrm{TCl}$ in very dilute concentrations. This off-gas will also contain $\mathrm{Ar}$ and $\mathrm{Cl}_{2}$. An analysis of potential recovery methods for $\mathrm{HCl} / \mathrm{TCl}$ identified a chemical conversion process and a liquid scrubbing process using sodium hydroxide solution as holding the most promise for the recovery of dilute $\mathrm{HCl}$ from an $\mathrm{Ar} / \mathrm{Cl}_{2}$ gas stream. Proof-of-principle experiments were designed to demonstrate $\mathrm{HCl}$ recovery with both potential processes using a non-radioactive simulant off-gas stream containing deuterium chloride (DCl). Use of $\mathrm{DCl}$ as a non-radioactive surrogate allows analysis of the liquids associated with each process by mass spectrometry.

The chemical conversion process was designed such that the simulant gas stream would pass through two heated solid beds, with the first bed containing finely divided copper shot, or steel wool, to convert $\mathrm{DCl}$ to $\mathrm{D}_{2}$, and the second bed containing $\mathrm{CuO}$ pellets to convert $\mathrm{D}_{2}$ to $\mathrm{D}_{2} \mathrm{O}$. This then allowed recovery of $\mathrm{D}_{2} \mathrm{O}$ by condensation for analysis. The liquid scrubbing process was designed to absorb the $\mathrm{DCl}$ from the gas stream using $\mathrm{NaOH}$ solution, which could be analyzed to determine the amount of $\mathrm{D}$ that had transferred into the solution.

Both methods were shown to recover D from the simulant gas stream. However, the recovery was not quantitative. The conversion and condensation method recovered up to $66 \%$ of the $\mathrm{D}$ based on mass recoveries, and up to $45 \%$ of the $\mathrm{D}$ based on instrumental analysis of the $\mathrm{D} / \mathrm{H}$ ratios. An additional experimental test with DCl-containing simulant was performed in an effort to quantify the recovery of $\mathrm{DCl}$ by a liquid scrubbing system. Recovery of $\mathrm{D}$ in this test was $59 \%$.

The liquid scrubbing system was selected for implementation in the planned hot-cell demonstration testing of the zirconium recycle process due to its simple design and lack of dependence on hot cell utilities. The parts for the hot-cell scrubber were purchased from commercial sources, with materials of construction including glass and polymeric materials. This system was successfully assembled. 
This page intentionally left blank. 


\section{CONTENTS}

SUMMARY iii

TABLES vii

ACRONYMS xi

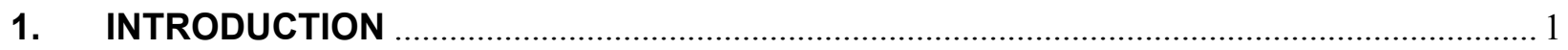

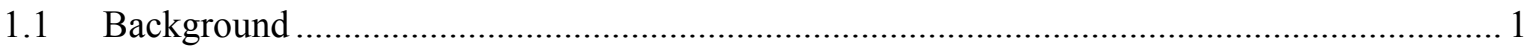

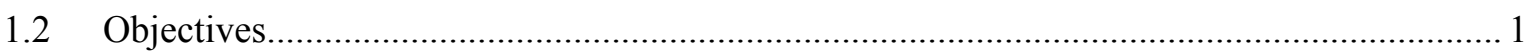

1.3 Estimated Off-Gas Composition of Zirconium Chlorination Process.................................. 2

2. ANALYSIS OF POTENTIAL HCI RECOVERY METHODS ............................................. 4

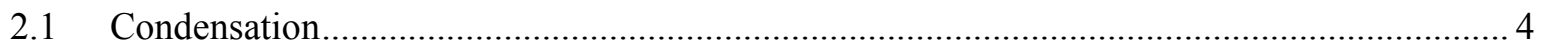

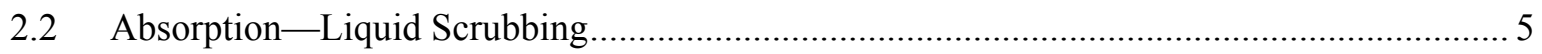

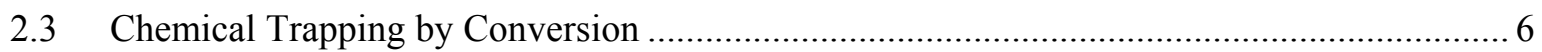

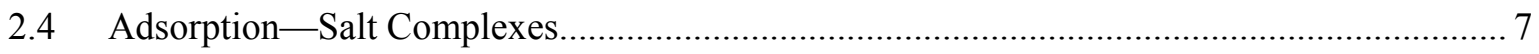

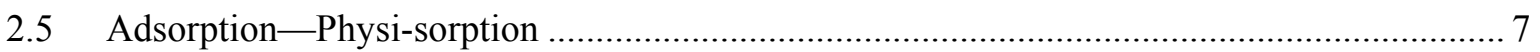

3. SELECTED CHEMICAL PROCESSES AND SYSTEM DESIGNS ….............................. 8

3.1 Conceptual Process Design for Chemical Conversion......................................................... 8

3.2 Conceptual Process Design for Liquid Scrubbing ........................................................... 10

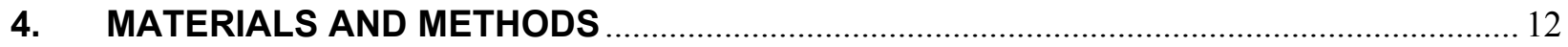

4.1 Demonstration of Chemical Conversion Process................................................................ 13

4.2 Demonstration of Liquid Scrubbing Process ....................................................................... 16

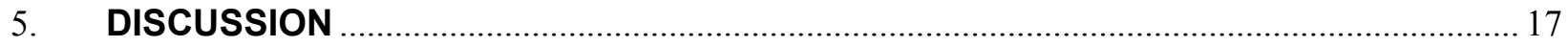

5.1 A System to Support Hot-Cell Zirconium Processing Operations...................................... 17

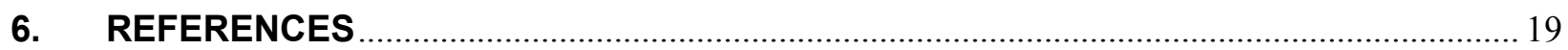


This page intentionally left blank. 


\section{TABLES}

Table 1. Quantities of hydrogen isotopes in typical used fuel ${ }^{\mathrm{a}}$............................................................. 2

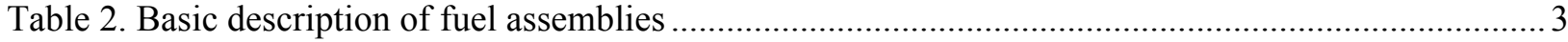

Table 3. Estimated composition of off-gas stream from cladding chlorination process............................. 4

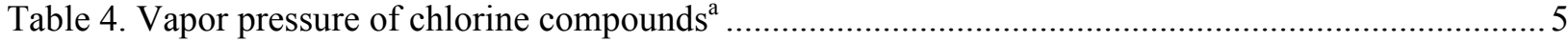

Table 5. Concentrations of components in prototypic off-gas stream …................................................ 10

Table 6. Analysis of condensate samples from conversion-cold trapping tests...................................... 15 
This page intentionally left blank. 


\section{FIGURES}

Figure 1. Solubility of chlorine in water solutions of $\mathrm{HCl}$ and $\mathrm{NaCl}-$ salt concentrations in wt \% (Adapted from Schmittinger 20009).

Figure 2. Adsorption capacity of molecular sieves (a) type 5A and (b) type $13 \mathrm{X}$ to trap $\mathrm{HCl}$ as a function of the partial pressure of gaseous $\mathrm{HCl}$ at $25^{\circ} \mathrm{C}$ (Adapted from Berl $1961^{15}$ ). 8

Figure 3. Conceptual process design for recovery of $\mathrm{HCl}$ from dilute off-gas streams by chemical conversion.

Figure 4. Conceptual process design for recovery of $\mathrm{HCl}$ from dilute off-gas streams by chemical conversion.

Figure 5. Conceptual process design for recovery of $\mathrm{HCl}$ from dilute off-gas streams by liquid scrubbing. 12

Figure 6. Experimental system for conversion approach to collecting deuterium as water. 13

Figure 7. Condensate recovered from second chemical conversion test... 14

Figure 8. Caustic scrubber to capture $\mathrm{DCl}$ from the synthetic off-gas stream. 16

Figure 9: Schematic of off-gas treatment system for use in zirconium recycle hot-cell demonstration 18

Figure 10: Assembled scrubber system 18 
This page intentionally left blank. 


\section{ACRONYMS}

$\begin{array}{ll}\text { BWR } & \text { boiling water reactor } \\ \text { g/MTIHM } & \text { gram(s) per metric ton initial heavy metal } \\ \text { ICP-MS } & \text { Inductively Coupled Plasma Mass Spectrometry } \\ \text { NIST } & \text { National Institute of Standards and Technology } \\ \text { ORIGEN } & \text { ORNL Isotope Generation and Depletion Code } \\ \text { ORNL } & \text { Oak Ridge National Laboratory } \\ \text { PWR } & \text { pressurized water reactor } \\ \text { UNF } & \text { used nuclear fuel } \\ \text { UT } & \text { The University of Tennessee }\end{array}$


This page intentionally left blank. 


\section{CAPTURE OF TRITIUM RELEASED FROM CLADDING IN THE ZIRCONIUM RECYCLE PROCESS}

\section{INTRODUCTION}

\subsection{Background}

Zirconium may be recovered from the Zircaloy® cladding of used nuclear fuel (UNF) for recycle or to reduce the quantities of high-level waste destined for a geologic repository. Either approach reduces the cost of recycling the fuel components of UNF. Zircaloy cladding contains high-value hafnium-free zirconium that may be recycled and result in substantial cost savings in the manufacture of new cladding. Alternatively, if the cladding is not recycled, processing reduces the volume of high-level waste zirconium significantly. The activity of the recovered zirconium should allow it to be treated as a lowlevel waste that may be disposed of by much less expensive means than a geologic repository. The cladding mass is about $25 \%$ of the fuel assembly mass and represents a substantial decrease in the amount of waste that must be disposed of in a geologic repository.

Recovery of zirconium using a chlorination process is currently under development at the Oak Ridge National Laboratory. The approach is to treat the cladding with chlorine gas to convert the zirconium in the alloy ( $\sim 98 \mathrm{wt} \%$ of the alloy mass), to zirconium tetrachloride. The $\mathrm{ZrCl}_{4}$ is volatile and readily separates from the non-volatile components, which may include highly radioactive oxide fuel fragments imbedded in the cladding by fission recoil. The general reaction of the chlorination process is shown in Eq. 1.

$$
\mathrm{Zr}(\mathrm{s})+2 \mathrm{Cl}_{2}(\mathrm{~g}) \rightarrow \mathrm{ZrCl}_{4}(\mathrm{~g})
$$

The alloying components may include either tin or niobium as major components ( $2 \mathrm{wt} \%)$, and minor or trace amounts of iron, nickel, and chromium, and traces of oxygen and nitrogen as impurities. The Sn and $\mathrm{Nb}$ may also volatilize during the process and subsequently can be separated from the $\mathrm{Zr}$ by fractionation. The other metals remain as a chloride ash. The product $\mathrm{ZrCl}_{4}$ is recovered as a solid salt by condensation when cooled to less than about $300^{\circ} \mathrm{C}$. A full description of the process was previously published. ${ }^{1}$

A fraction of the tritium (0-96\%) produced in nuclear fuel during irradiation is found in zirconium based cladding. ${ }^{2}$ Tritium is not found in stainless steel (SS) cladding, nor are the expected amounts found in the used fuel. Tritium easily diffuses through the thin SS clad and enters the reactor coolant. Because tritium is found in both the used fuel and the Zircaloy cladding, it is generally thought that the tritium that migrates to the Zircaloy cladding is chemically trapped in the cladding as a zirconium hydride. The tritium is released from the cladding when it is heated for a prolonged time or when the solid matrix is destroyed by the chlorination reaction (Eq. 1). To prevent uncontrolled release of radioactive tritium to other parts of the plant or to the environment, a method to recover the tritium is required.

\subsection{Objectives}

The focus of this effort was to (1) identify potential methods for the recovery of tritium from the off-gas of the zirconium recycle process, (2) perform scoping tests on selected recovery methods using nonradioactive gas simulants, and (3) select a process design that is appropriate for testing on radioactive gas streams generated from engineering-scale zirconium recycle demonstrations on radioactive used cladding. 


\subsection{Estimated Off-Gas Composition of Zirconium Chlorination Process}

Unambiguous identification of the chemical form of the tritium in the cladding is not available. It is known that heating the cladding to high temperatures releases the tritium. ${ }^{2}$ Conversion of the metal cladding components to chloride forms is also expected to release the tritium, either as free hydrogen that can react with chlorine to produce $\mathrm{HCl}$ (i.e., ${ }^{3} \mathrm{HCl}$ ) (Equation 2) or directly as ${ }^{3} \mathrm{HCl}$ during the chlorination reaction, as shown in Equation 3.

$$
\begin{aligned}
& \mathrm{H}_{2}(\mathrm{~g})+\mathrm{Cl}_{2}(\mathrm{~g}) \rightarrow 2 \mathrm{HCl}(\mathrm{g}) \\
& \mathrm{ZrH}_{\mathrm{x}}(\mathrm{s})+(2+\mathrm{x} / 2) \mathrm{Cl}_{2}(\mathrm{~g}) \rightarrow \mathrm{ZrCl}_{4}(\mathrm{~g})+\mathrm{xHCl}(\mathrm{g})
\end{aligned}
$$

In the $\mathrm{Zr}$ recovery process, the $\mathrm{ZrCl}_{4}$ is condensed as a fine particulate, solid phase. There is the potential that a portion of the ${ }^{3} \mathrm{HCl}$ will hydrogen bond to the $\mathrm{ZrCl}_{4}$, or other chloride product $\left(\mathrm{SnCl}_{4} \mathrm{Or} \mathrm{NbCl}_{3}\right)$, complicating the separation of tritium from the product. Until further data are available, it is assumed that the ${ }^{3} \mathrm{HCl}$ remains in the gas phase when the metal chlorides condense. This assumption is reasonable in view of the high temperatures at which the subject metal chlorides desublime. Specifically, the boiling points are $\mathrm{HCl},-84.9{ }^{\circ} \mathrm{C} ; \mathrm{SnCl}_{4}, 114{ }^{\circ} \mathrm{C} ; \mathrm{NbCl}_{5}, 254{ }^{\circ} \mathrm{C}$; and $\mathrm{ZrCl}_{4}, 331{ }^{\circ} \mathrm{C}$.

The quantities of hydrogen (including ${ }^{3} \mathrm{H}$ ) in modern pressurized water reactor (PWR) UNF are summarized in Table 1 and are shown to be very small. To estimate the concentration of the ${ }^{3} \mathrm{HCl}$ concentration in the off-gas from the Zircaloy chlorinator, the amount of Zircaloy associated with the ${ }^{3} \mathrm{H}$ is required. Table 2 provides data on the characteristics of both PWR and boiling water (BWR) reactor fuel assemblies. From this table it is readily calculated that BWR assemblies contain $0.543 \mathrm{~kg}$ Zircaloy $/ \mathrm{kg} \mathrm{U}$ whereas PWR assemblies contain $0.235 \mathrm{~kg}$ Zircaloy $/ \mathrm{kg} \mathrm{U}$. Thus, all other variables being equal, the off-gas from processing PWR Zircaloy should be higher in ${ }^{3} \mathrm{H}$ concentration than off-gas from processing BWR Zircaloy assemblies. As a first step, consider the case of processing PWR Zircaloy, realizing that the recovery of ${ }^{3} \mathrm{H}$ from leaner off-gas streams will be more difficult.

Table 1. Quantities of hydrogen isotopes in typical used fuel ${ }^{\mathrm{a}}$

\begin{tabular}{|c|c|c|c|c|c|c|}
\hline \multirow{2}{*}{ Isotope } & \multicolumn{2}{|c|}{$\begin{array}{c}\text { Activation products } \\
\text { (g/MTIHM) }\end{array}$} & \multicolumn{2}{c|}{ Fission products } & \multicolumn{2}{c|}{$\begin{array}{c}\text { Activation + fission } \\
\text { products }\end{array}$} \\
& (Ci/MTIHM) & (g/MTIHM) & (Ci/MTIHM) & (g/MTIHM) & (Ci/MTIHM) \\
\hline${ }^{1} \mathrm{H}$ & $1.35 \mathrm{E}-2$ & 0 & 0 & 0 & $1.35 \mathrm{E}-2$ & 0 \\
\hline${ }^{2} \mathrm{H}$ & $1.32 \mathrm{E}-5$ & 0 & 0 & 0 & $1.32 \mathrm{E}-5$ & 0 \\
\hline${ }^{3} \mathrm{H}$ & $2.19 \mathrm{E}-2$ & $2.11 \mathrm{E}+2$ & $6.84 \mathrm{E}-2$ & $6.60 \mathrm{E}+2$ & $9.03 \mathrm{E}-2$ & $8.71 \mathrm{E}+2$ \\
\hline
\end{tabular}

${ }^{a}$ Oak Ridge National Laboratory (ORNL) Isotope Generation and Depletion Code (ORIGEN) calculation based on pressurized water reactor (PWR) fuel at a burnup of $55 \mathrm{GWd} / \mathrm{MTIHM}$ and cooling time of five years. 
Table 2. Basic description of fuel assemblies

\begin{tabular}{|c|c|c|c|}
\hline Characteristic & BWR & PWR & Reference \\
\hline Fuel Pin O.D. (cm) & 1.252 & 0.95 & \multirow[t]{7}{*}{ Croff and Alexander $1980^{4}$} \\
\hline Fuel Pin Active Length (m) & 3.759 & 3.658 & \\
\hline Fuel Pin Total Length (m) & 4.064 & 3.851 & \\
\hline Fuel Pins/Assembly & 63 & 264 & \\
\hline U/Assembly (kg) & 183.3 & 461.4 & \\
\hline $\mathrm{UO}_{2} /$ Assembly $(\mathrm{kg})$ & 208.0 & 524.4 & \\
\hline $\mathrm{Zr} /$ Assembly $(\mathrm{kg})^{a}$ & 99.5 & 108.4 & \\
\hline Cladding O.D. (mm) & 12.294 & 9.4996 & \multirow{4}{*}{$\begin{array}{l}\text { For } 8 \times 8 \text { BWR: } \\
\text { Cochran and Tsoulfanidis } 1999 \\
\text { For } 17 \times 17 \text { PWR: } \\
\text { Gehin and Primm } 1997^{6}\end{array}$} \\
\hline Cladding thickness (mm) & 0.889 & 0.5715 & \\
\hline Pellet O.D. (mm) & 10.274 & 8.1915 & \\
\hline Inferred clearance $(\mathrm{mm})$ & 0.121 & 0.08255 & \\
\hline
\end{tabular}

${ }^{a}$ Includes Zircaloy control rod guide thimbles.

Additional assumptions are required to obtain an order of magnitude estimate of the ${ }^{3} \mathrm{H}$ concentration in the off-gas stream:

- Half of the hydrogen (tritium) in the fuel migrated to, and resides in, the cladding.

- Feed gas stream is a mixture of $50 \% \mathrm{Ar}-50 \% \mathrm{Cl}_{2}$ by volume.

- Zirconium content of cladding is completely converted to $\mathrm{ZrCl}_{4}$ (true for continuous operations).

- Remaining metal constituent is tin and is completely converted to $\mathrm{SnCl}_{4}$.

- No other components other than $\mathrm{ZrCl}_{4}$ and $\mathrm{SnCl}_{4}$ are volatile except the hydrogen (tritium).

- The hydrogen arising from the fuel cladding is converted to $\mathrm{HCl}$.

- Average chlorine utilization over the entire time of metal conversion is $95 \%$.

- The $\mathrm{ZrCl}_{4}$ and $\mathrm{SnCl}_{4}$ products are condensed as solid salts.

- The remaining off-gas stream consists of the Ar, residual $\mathrm{Cl}_{2}$, residual $\mathrm{SnCl}_{4}$, and $\mathrm{HCl}$.

Using the listed assumptions, the average off-gas stream composition for the zirconium chlorination process was estimated by material balance; the results are shown in Table 3. All hydrogen arising from the dry cladding results in an $\mathrm{HCl}$ concentration of about $4 \mathrm{ppmv}$ (parts per million by volume); the tritiated $\mathrm{HCl}\left({ }^{3} \mathrm{HCl}\right)$ portion is about $3 \mathrm{ppmv}$. The activity of tritium in the off-gas is estimated at $3.47 \mathrm{mCi} / \mathrm{std}$ L. (Note: Some modern claddings use niobium instead of tin as the minor alloy component. Niobium also volatilizes as $\mathrm{NbCl}_{3}$ and/or $\mathrm{NbCl}_{5}$, and for such modern claddings much of the preceding remarks apply equally well.) 
Table 3. Estimated composition of off-gas stream from cladding chlorination process

\begin{tabular}{|l|c|}
\hline Component & Concn. (v/v) \\
\hline $\mathrm{Ar}$ & 0.952 \\
\hline $\mathrm{Cl}_{2}$ & 0.0476 \\
\hline $\mathrm{HCl}$ & $1.19 \mathrm{E}-06$ \\
\hline${ }^{2} \mathrm{HCl}$ & $5.83 \mathrm{E}-10$ \\
\hline${ }^{3} \mathrm{HCl}$ & $2.66 \mathrm{E}-06$ \\
\hline TOTAL & 1.000 \\
\hline & \\
\hline${ }^{\text {all }} \mathrm{HCl}$ & $3.85 \mathrm{E}-06$ \\
\hline
\end{tabular}

\section{ANALYSIS OF POTENTIAL HCI RECOVERY METHODS}

Several methods were considered for separation of ${ }^{3} \mathrm{HCl}$ from the $\mathrm{Ar}-\mathrm{Cl}_{2}$ mixture. These methods are summarized in this section.

\subsection{Condensation}

The normal boiling points of $\mathrm{Ar}, \mathrm{HCl}$ and $\mathrm{Cl}_{2}$ are $-189.3{ }^{\circ} \mathrm{C},-84.9{ }^{\circ} \mathrm{C}$, and $-34.6{ }^{\circ} \mathrm{C}$, respectively. ${ }^{3}$ This indicates $\mathrm{Cl}_{2}$ condenses before $\mathrm{HCl}$. The vapor pressures of chloride compounds of interest are shown in Table 4, with the vapor pressure of $\mathrm{HCl}$ being $25.7 \mathrm{~atm}$ and that of $\mathrm{Cl}_{2}$ being $3.6 \mathrm{~atm}\left(\right.$ at $\left.0{ }^{\circ} \mathrm{C}\right)$. If the offgas is at a total pressure of about $1 \mathrm{~atm}$, the partial pressure of the $\mathrm{HCl}$ in the off-gas is less than its vapor pressure at temperatures as low as $-100{ }^{\circ} \mathrm{C}$. Thus none of it would condense (i.e., a partial pressure of $\sim 4 \times 10^{-6} \mathrm{~atm}$, based on Table 3, versus a vapor pressure of about $0.4 \mathrm{~atm}$ as shown in Table 4). In contrast, the majority of $\mathrm{Cl}_{2}$ present in the off-gas stream would condense at $-100{ }^{\circ} \mathrm{C}$, and the remainder subsequently could condense at lower temperatures with the $\mathrm{HCl}$. Thus, to use condensation as an $\mathrm{HCl}$ recovery method, a two-stage condenser system would be required for separation of $\mathrm{Cl}_{2}$ from $\mathrm{HCl}$.

However, the freezing points of $\mathrm{Cl}_{2}\left(-101.0^{\circ} \mathrm{C}\right)$ and $\mathrm{HCl}\left(-114.8^{\circ} \mathrm{C}\right)$ present practical concerns for recovery by condensation. Typical coolants such as liquid $\mathrm{N}_{2}$ or liquid Ar would tend to condense both $\mathrm{Cl}_{2}$ and $\mathrm{HCl}$ as solids. If the solids were acceptable, use of liquid Ar would be preferable because liquid $\mathrm{N}_{2}$ can condense the Ar from the off-gas stream of the chlorination process, causing excessive pressures as the trap warms to room temperature.

A further concern regarding $\mathrm{HCl}$ recovery by condensation is that very low concentrations of $\mathrm{HCl}$ may be soluble in $\mathrm{Cl}_{2}$. Solubility would manifest itself as an apparent condensation of both compounds in the first liquid product condenser, or there could be partitioning of the $\mathrm{HCl}$ between liquid and gas phases, complicating the recovery and measurement of the ${ }^{3} \mathrm{HCl}$. This concern may only apply at extremely low concentrations of $\mathrm{HCl}$ because liquefaction of $\mathrm{Cl}_{2}$ has been cited as a method to industrially separate the $\mathrm{HCl}$ impurity from the $\mathrm{Cl}_{2}$ product. ${ }^{7}$ Should there be slight solubility of $\mathrm{HCl}$ in liquid $\mathrm{Cl}_{2}$, the addition of $\mathrm{HCl}$ containing only natural isotopic ratios of hydrogen upstream of the separation process saturates the liquid phase with mostly the $\mathrm{HCl}$. This technique leaves most of the ${ }^{3} \mathrm{HCl}$ in the gas phase so that it may be recovered for analysis. Condensation processes do appear to present merit, but the concerns raised in this analysis indicate that the level of complexity for the condensation operation may be undesirable for use in radioactive operations conducted in hot cells. 
Table 4. Vapor pressure of chlorine compounds ${ }^{\mathrm{a}}$

\begin{tabular}{|l|c|c|c|c|c|c|}
\hline \multirow{2}{*}{$\mathbf{T}\left({ }^{\circ} \mathbf{C}\right)$} & $\mathbf{Z r C l}_{\mathbf{4}}$ & $\mathbf{S n C l}_{\mathbf{4}}$ & $\mathbf{C l}_{\mathbf{2}}(\mathbf{l o})$ & $\mathbf{C l}_{\mathbf{2}}$ (hi) & $\mathbf{H C l}(\mathbf{l o})$ & $\mathbf{H C l}(\mathbf{h i})$ \\
\cline { 2 - 7 } & $P(\mathrm{~atm})$ & $P(\mathrm{~atm})$ & $P(\mathrm{~atm})$ & $P(\mathrm{~atm})$ & $P(\mathrm{~atm})$ & $P(\mathrm{~atm})$ \\
\hline-195.8 & $1.91 \mathrm{E}-113$ & $8.09 \mathrm{E}-57$ & $1.87 \mathrm{E}-39$ & $1.81 \mathrm{E}-11$ & $2.15 \mathrm{E}-11$ & $3.90 \mathrm{E}-07$ \\
\hline-100 & $2.90 \mathrm{E}-28$ & $3.30 \mathrm{E}-08$ & $1.34 \mathrm{E}-02$ & $1.71 \mathrm{E}-02$ & $3.87 \mathrm{E}-01$ & $4.01 \mathrm{E}-01$ \\
\hline-75 & $1.19 \mathrm{E}-22$ & $3.51 \mathrm{E}-06$ & $1.10 \mathrm{E}-01$ & $1.12 \mathrm{E}-01$ & $1.66 \mathrm{E}+00$ & $1.68 \mathrm{E}+00$ \\
\hline-50 & $1.52 \mathrm{E}-18$ & $9.38 \mathrm{E}-05$ & $4.66 \mathrm{E}-01$ & $4.69 \mathrm{E}-01$ & 4.811939 & $5.10 \mathrm{E}+00$ \\
\hline-25 & $2.09 \mathrm{E}-15$ & $1.07 \mathrm{E}-03$ & $1.33 \mathrm{E}+00$ & $1.45 \mathrm{E}+00$ & $1.08 \mathrm{E}+01$ & $1.24 \mathrm{E}+01$ \\
\hline 0 & $6.22 \mathrm{E}-13$ & $7.03 \mathrm{E}-03$ & $2.96 \mathrm{E}+00$ & $3.60 \mathrm{E}+00$ & $2.03 \mathrm{E}+01$ & $2.57 \mathrm{E}+01$ \\
\hline 25 & $6.24 \mathrm{E}-11$ & $3.14 \mathrm{E}-02$ & $5.54 \mathrm{E}+00$ & $7.64 \mathrm{E}+00$ & $3.39 \mathrm{E}+01$ & $4.71 \mathrm{E}+01$ \\
\hline 100 & $1.04 \mathrm{E}-06$ & $6.80 \mathrm{E}-01$ & $1.98 \mathrm{E}+01$ & $3.90 \mathrm{E}+01$ & $9.91 \mathrm{E}+01$ & $1.79 \mathrm{E}+02$ \\
\hline 200 & $2.44 \mathrm{E}-03$ & $7.41 \mathrm{E}+00$ & $5.21 \mathrm{E}+01$ & $1.50 \mathrm{E}+02$ & $2.33 \mathrm{E}+02$ & $5.49 \mathrm{E}+02$ \\
\hline 300 & $3.17 \mathrm{E}-01$ & $3.21 \mathrm{E}+01$ & $9.38 \mathrm{E}+01$ & $3.56 \mathrm{E}+02$ & $3.97 \mathrm{E}+02$ & $1.14 \mathrm{E}+03$ \\
\hline 400 & $8.95 \mathrm{E}+00$ & $8.68 \mathrm{E}+01$ & $1.39 \mathrm{E}+02$ & $6.51 \mathrm{E}+02$ & $5.71 \mathrm{E}+02$ & $1.91 \mathrm{E}+03$ \\
\hline 450 & $3.30 \mathrm{E}+01$ & $1.28 \mathrm{E}+02$ & $1.62 \mathrm{E}+02$ & $8.26 \mathrm{E}+02$ & $6.59 \mathrm{E}+02$ & $2.35 \mathrm{E}+03$ \\
\hline
\end{tabular}

${ }^{a}$ Calculated with the Antoine equation using coefficients found at the NIST Webbook. ${ }^{8}$ For some compounds, the reference gives two correlations, one for a low-temperature range and one for a high-temperature range. Where two correlations are provided, the table shows calculated values for both (hi and lo) correlations for all temperatures listed although the listed temperatures may be outside the recommended range. Green highlighted values indicate those temperatures within the range of the correlation; all others are extrapolated using the same correlation. Lowest temperature shown is the boiling point of liquid nitrogen.

\subsection{Absorption—Liquid Scrubbing}

Hydrogen chloride may be removed from gaseous $\mathrm{Cl}_{2}$ by scrubbing with water, and it has been used industrially. ${ }^{9} \mathrm{HCl}$ is more soluble in water and is readily scrubbed. Much of the $\mathrm{Cl}_{2}$ present within the offgas will pass through the scrubber, but a fraction will enter solution and convert to $\mathrm{HCl}$. $\mathrm{SnCl}_{4}$ is also soluble in cold water and will decompose in warm water to form $\mathrm{HCl}$ and possibly $\mathrm{SnOCl}_{2}$ or $\mathrm{SnO}_{2}$. In a recirculating scrubber, as might be used to collect ${ }^{3} \mathrm{HCl}$ for analysis, the acidity of the water increases as $\mathrm{HCl}$ concentration increases. The solubility of $\mathrm{Cl}_{2}$ increases as the acidity increases, but decreases as chloride salt concentration increases (Figure 1). Scrubber solutions of $\mathrm{NaCl}$ or $\mathrm{KCl}$, augmented with $\mathrm{NaOH}$ or $\mathrm{KOH}$ to neutralize the $\mathrm{HCl}$ as it is absorbed, may be the most effective. The resulting $\mathrm{Cl}_{2}$ gas stream will contain water vapor: Industrially the stream is dried with concentrated $\mathrm{H}_{2} \mathrm{SO}_{4}$. Because the small-scale tests will likely not require the recycle of $\mathrm{Cl}_{2}$, a drying step will not be necessary.

Carbon tetrachloride $\left(\mathrm{CCl}_{4}\right)$ has also been utilized for chlorine scrubbing industrially. ${ }^{9}$ Chlorine is very soluble in $\mathrm{CCl}_{4}$, whereas the $\mathrm{HCl}$ impurity is not soluble. Tin tetrachloride is also soluble in $\mathrm{CCl}_{4}{ }^{10}{ }^{1}$ To achieve separation of $\mathrm{Cl}_{2}$ from $\mathrm{HCl}, \mathrm{HCl}$ could be recovered by a second scrubber. Industrially, recovered $\mathrm{Cl}_{2}$ is desorbed from the $\mathrm{CCl}_{4}$ scrubber solution by heating, but in an experimental program it may be neutralized and sent to waste. 


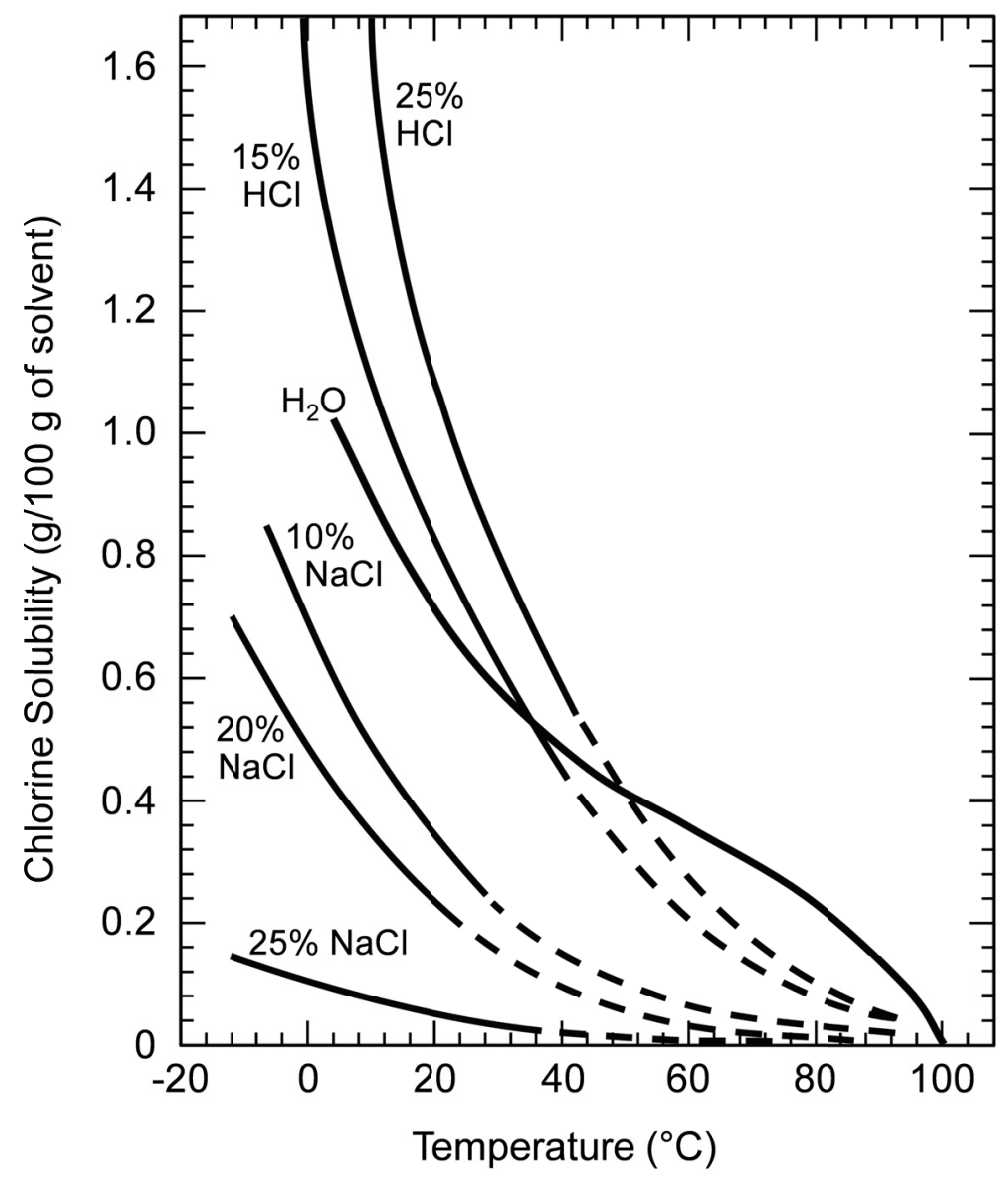

Figure 1. Solubility of chlorine in water solutions of $\mathrm{HCl}$ and $\mathrm{NaCl}-$ salt concentrations in wt \% (Adapted from Schmittinger $2000^{9}$ ).

\subsection{Chemical Trapping by Conversion}

In addition to direct recovery of tritium through $\mathrm{HCl}$ capture, chemical conversion was evaluated for the potential to convert $\mathrm{HCl}$ to other forms that would permit straightforward tritium recovery. In most gassolid reactions involving $\mathrm{Cl}_{2}$ and $\mathrm{HCl}$, a selective chemical reaction to exclusively convert or adsorb only one of these compounds, and thus effect a separation, has not yet been identified. However, gas-solid reactions of $\mathrm{HCl}$ and $\mathrm{Cl}_{2}$ may produce different products when reacting with the same sorbent. For example, $\mathrm{HCl}$ reacts with copper to form copper chloride and release the hydrogen, while $\mathrm{Cl}_{2}$ produces only solid copper chloride (Equations 4 and 5). The hydrogen released from the reaction of $\mathrm{HCl}$ with a copper sorbent subsequently could be converted to water with a hot copper oxide catalyst (Equation 6).

$$
\begin{array}{ll}
\mathrm{HCl}(\mathrm{g})+\mathrm{Cu}(\mathrm{s}) \rightarrow \mathrm{CuCl}(\mathrm{s})+1 / 2 \mathrm{H}_{2}(\mathrm{~g}) & \left(\Delta \mathrm{G} \sim-9.2 \mathrm{kcal} / \mathrm{mol} \text { at } 100{ }^{\circ} \mathrm{C}\right) \\
\mathrm{Cl}_{2}(\mathrm{~g})+2 \mathrm{Cu}(\mathrm{s}) \rightarrow 2 \mathrm{CuCl}(\mathrm{s}) & \left(\Delta \mathrm{G} \sim-55.1 \mathrm{kcal} / \mathrm{mol} \text { at } 100{ }^{\circ} \mathrm{C}\right) \\
\mathrm{H}_{2}(\mathrm{~g})+\mathrm{CuO}(\mathrm{s}) \rightarrow \mathrm{Cu}(\mathrm{s})+\mathrm{H}_{2} \mathrm{O}(\mathrm{g}) & \left(\Delta \mathrm{G} \sim-24.5 \mathrm{kcal} / \mathrm{mol} \text { at } 100{ }^{\circ} \mathrm{C}\right)
\end{array}
$$

The tin chloride, which is in lesser abundance compared to the $\mathrm{Cl}_{2}$, will also consume some copper, as shown in Equation 7.

$$
2 \mathrm{Cu}(\mathrm{s})+\mathrm{SnCl}_{4}(\mathrm{~g}) \rightarrow 2 \mathrm{CuCl}(\mathrm{s})+\mathrm{SnCl}_{2}(\mathrm{~s}) \quad\left(\Delta \mathrm{G} \sim-3.5 \mathrm{kcal} \text { at } 100^{\circ} \mathrm{C}\right)
$$


The copper could be replenished periodically, and the copper oxide catalyst could be regenerated with oxygen periodically. Such a two-step method appears feasible, but because the first copper bed will consume both $\mathrm{HCl}$ and $\mathrm{Cl}_{2}$, copper consumption on an industrial scale may pose an economic concern. The conversion operation potentially could be performed with a less expensive d-block metal, such as iron (Eqn. 8).

$$
2 \mathrm{HCl}(\mathrm{g})+\mathrm{Fe}(\mathrm{s}) \rightarrow \mathrm{FeCl}_{2}(\mathrm{~s})+\mathrm{H}_{2}(\mathrm{~g}) \quad\left(\Delta \mathrm{G} \sim-23.9 \mathrm{kcal} / \mathrm{mol} \text { at } 100{ }^{\circ} \mathrm{C}\right)
$$

This process appears to achieve disposal of the residual $\mathrm{Cl}_{2}$ while recovering the tritium for analysis using primarily solid reactants, which is attractive for hot cell operations.

\subsection{Adsorption-Salt Complexes}

A literature review indicates that halides can be separated from their acid form by adsorption processes that produce salt complexes. A well-known example of such a process is the use of NaF to sorb HF while $\mathrm{F}_{2}$ passes through the sorption column. The salt complex is often called sodium bifluoride (NaF.HF or $\mathrm{NaHF}_{2}$ ). The adsorption is reversible, with adsorption occurring at low temperatures (around $25^{\circ} \mathrm{C}$ ) and desorption occurring above $150^{\circ} \mathrm{C}$. Little information on analogous adsorption processes for $\mathrm{HCl}$ was found. Available spectroscopic data indicate that cesium halides, such as $\mathrm{CsCl}$, hydrogen bond with $\mathrm{HCl}^{11}$ Sodium fluoride may also sorb $\mathrm{HCl}$ via hydrogen bonding. No information on the sorption capacity of high surface area alkali halides for $\mathrm{HCl}$ was found. Although recovery of $\mathrm{HCl}$ through the formation of salt complexes seems to hold promise, the fundamental science of such a process appears unconfirmed.

\subsection{Adsorption-Physi-sorption}

The most common solid adsorbents applicable to the present application are activated carbon and zeolites. The molecular diameter of $\mathrm{Cl}_{2}$ is about $8.2 \AA$ (EMDMillipore ${ }^{12}$ ) and that of $\mathrm{HCl}$ ranges over 4-5 $\AA$ (Eng and Greenwood $\left.^{7}\right)$. Another reference $\left(\mathrm{Semco}^{13}\right)$ indicates that both molecules have kinetic diameters between 3-4 $\AA$ and recommends using a $3 \mathrm{~A}$ molecular sieve for removing trace amounts of these compounds from air to improve indoor air quality. Due to the disparity in this foundational data, improved information on the molecular sizes is needed before the viability of solid adsorbents for $\mathrm{HCl}$ recovery can be evaluated. However, there are some indications within the literature that such processes may be practical.

Activated carbon (ChemSorb 1202) is recommended by one manufacturer for adsorption of acid gases and chlorine. ${ }^{14}$ This product has a very large specific surface area $\left(1000 \mathrm{~m}^{2} / \mathrm{g}\right)$ and pore sizes ranging from 5-10 $\AA$. It does not appear to selectively adsorb either of the two molecules (i.e., $\mathrm{Cl}_{2}$ or $\mathrm{HCl}$ ), thereby providing little advantage over other processes that collect both species together. In operation, the sorbed compounds would need to be released in a regeneration step (heating the sorbent while flowing a carrier gas through the bed of sorbent) and then captured by another technique for analysis.

Zeolite-based molecular sieves have greater affinity for polar molecules (e.g., $\mathrm{HCl}$ ). Eng and Greenwood ${ }^{7}$ recommend a zeolite with a $5 \AA$ aperture for sorbing $\mathrm{HCl}$ from a $\mathrm{Cl}_{2}$ product. Berl ${ }^{15}$ provides a graphic for the $\mathrm{HCl}$ capacity of both 5A and $13 \mathrm{X}$ molecular sieves as shown in Fig. 2. Capacity of about 13-21 wt \% is indicated at a temperature of $25^{\circ} \mathrm{C}$, but only at very high gas phase $\mathrm{HCl}$ concentrations. Additional data are needed on how these molecular sieves (or at least one of them) perform at very low $\mathrm{HCl}$ concentrations. Alternately, additional $\mathrm{HCl}$ (naturally occurring hydrogen) could be added to the off-gas stream to boost the total $\mathrm{HCl}$ partial pressure to around $1 \mathrm{~mm} \mathrm{Hg}$ (concentration of $\sim 1.4 \times 10^{-3} \mathrm{v} / \mathrm{v}$ ) to capture a sufficient fraction of the ${ }^{3} \mathrm{HCl}$ to provide a reliable analysis. Cooling of the molecular sieve trap 
may also improve its performance, particularly for lean $\mathrm{HCl}$ streams. This approach appears promising for $\mathrm{HCl}$ recovery, but additional data are needed on how these molecular sieves (or at least one of them) perform in the present application.

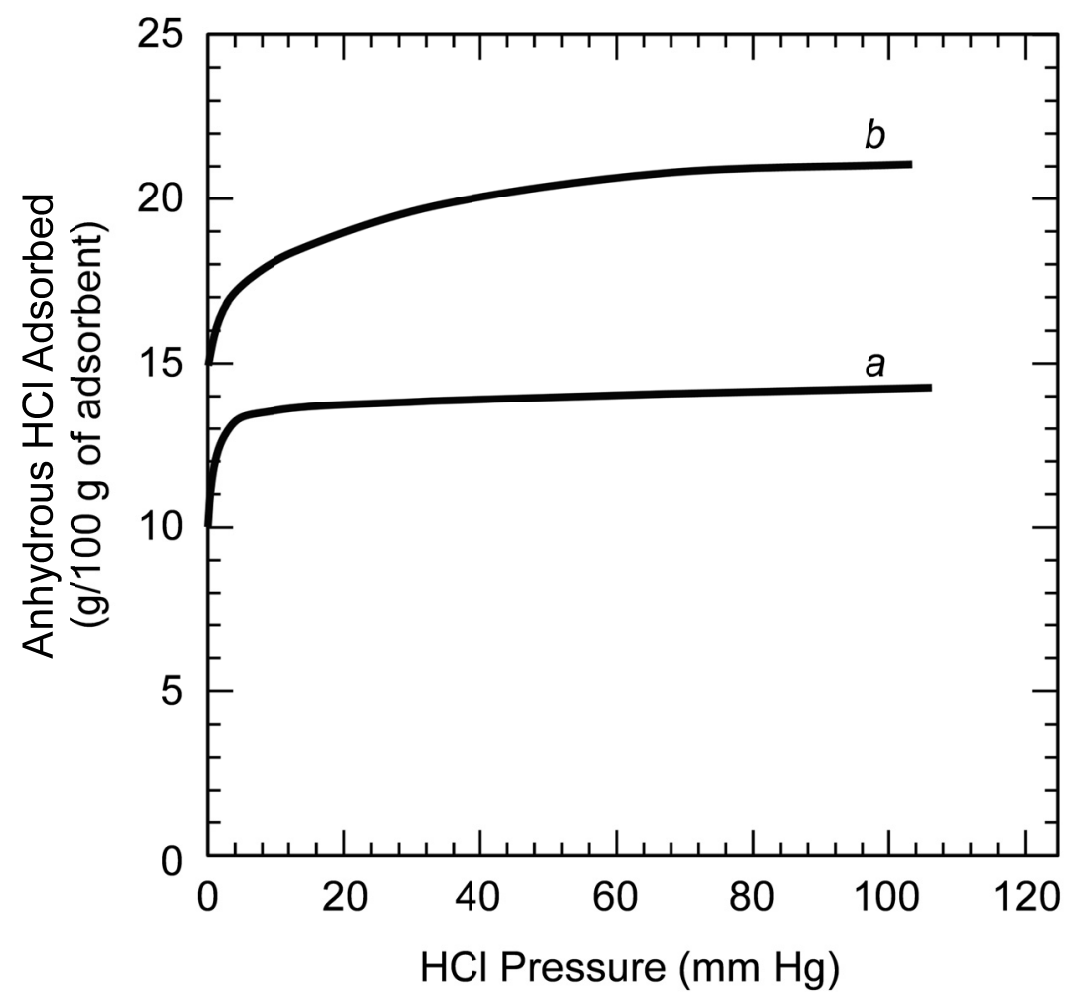

Figure 2. Adsorption capacity of molecular sieves (a) type $5 \mathrm{~A}$ and (b) type $13 \mathrm{X}$ to trap $\mathrm{HCl}$ as a function of the partial pressure of gaseous $\mathrm{HCl}$ at $25^{\circ} \mathrm{C}$ (Adapted from Berl $1961^{15}$ ).

\section{SELECTED CHEMICAL PROCESSES AND SYSTEM DESIGNS}

Upon completion of the literature review, chemical conversion and liquid scrubbing were determined to hold the most promise for the recovery of dilute $\mathrm{HCl}$ from an $\mathrm{Ar} / \mathrm{Cl}_{2}$ gas stream for near term application. Condensation appears excessively complex for hot cell operations, and the remaining technologies that were evaluated all require a level of fundamental research and development that is outside the scope of this effort.

Proof-of-principle experiments to demonstrate $\mathrm{HCl}$ recovery with both selected processes were designed to be performed with the use of a non-radioactive simulant off-gas stream. Deuterium chloride (DCl) is readily available in gaseous form, and deuterium concentrations in the recovered water from the chemical conversion process and in the liquid scrubber solution can be determined by mass spectrometry.

\subsection{Conceptual Process Design for Chemical Conversion}

A process design for the chemical conversion process is shown in Figure 3. 


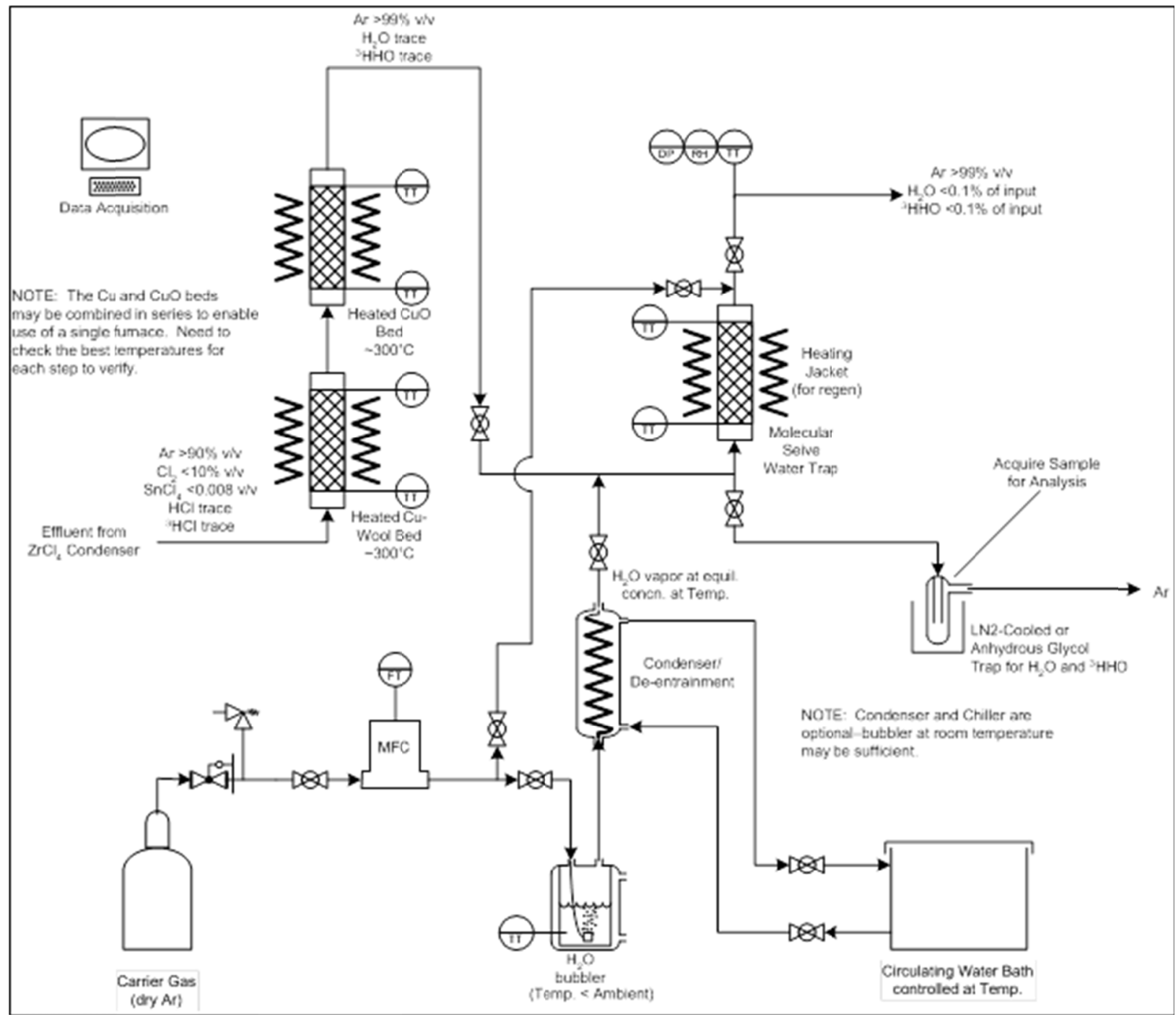

Figure 3. Conceptual process design for recovery of $\mathrm{HCl}$ from dilute off-gas streams by chemical conversion.

In this design, the simulated effluent from the zirconium recycle process is expected to contain primarily $\mathrm{Ar}, \mathrm{Cl}_{2}, \mathrm{SnCl}_{4}$, and $\mathrm{HCl}$ in the concentrations shown in Table 5. This stream is directed through a heated sorbent column containing $\mathrm{Cu}$ beads (iron or steel wool will also work and are less expensive). The effluent from the copper bed is assumed to then contain ${ }^{3} \mathrm{H}$ as hydrogen gas, based on Equation 4, and very little chlorine, based on Equation 5 . The ${ }^{3} \mathrm{H}$-containing effluent is directed into a heated $\mathrm{CuO}$ bed where the hydrogen gas is converted to water as in Equation 6. This water vapor can be condensed through a variety of techniques; adsorption on regenerable molecular sieve sorbents and recovery through condensation with a cold trap are both shown in Figure 3. This system is not selective, and it will consume $\mathrm{Cl}_{2}$ and $\mathrm{SnCl}_{4}$ in addition to converting $\mathrm{HCl}$ (Equations 5,7). This approach is intended to recover the tritium in concentrated form and is intended for small-scale experiments. It is not likely to be the method of choice for full-scale or commercial applications because of the large amounts of metal chloride waste that would be produced. 
Table 5. Concentrations of components in prototypic offgas stream

\begin{tabular}{|c|c|}
\hline Component & $\begin{array}{c}\text { Concentration } \\
(\mathbf{\%} / \mathbf{v})\end{array}$ \\
\hline $\mathrm{Ar}$ & 90 \\
\hline $\mathrm{Cl}_{2}$ & 10 \\
\hline $\mathrm{SnCl}_{4}$ & 0.008 \\
\hline $\mathrm{HCl} /{ }^{3} \mathrm{HCl}$ & trace \\
\hline
\end{tabular}

In the case of the proof-of-principle experiments reported in Sect. 4, the following simplifications were incorporated:

1) $\mathrm{DCl}$ was used as a stand-in for all of the isotopically different $\mathrm{HCl}$ compounds, with a total concentration in the gas stream of $\sim 2 \% \mathrm{v} / \mathrm{v}$.

2) $\mathrm{SnCl}_{4}$ and $\mathrm{Cl}_{2}$ were not included in the prototypic stream.

3) The reducing metal was iron (as steel wool); the surface area per unit mass was much greater than that of the available copper shot.

4) A cold trap was selected to condense the water present in the effluent, and the molecular sieve trap was not utilized.

Features of a simplified system using blends of bottled gases are illustrated in Fig. 4.

\subsection{Conceptual Process Design for Liquid Scrubbing}

For the conceptual liquid scrubbing system shown in Figure 5, the effluent from the zirconium chlorination process is sent directly into a packed column scrubber. This scrubber will remove $\mathrm{HCl}$ and $\mathrm{SnCl}_{4}$ from the off-gas stream while allowing the bulk of the $\mathrm{Cl}_{2}$ to pass through the column. The scrubber can be equipped with a recirculating scrub solution, if desired, which will allow for $\mathrm{pH}$ adjustment and sampling of the solution at selected intervals. The effluent from the liquid scrubber is directed through a condenser to remove any aerosols entrained within the gas, and then can either be passed through a chlorine neutralization column or vented directly. Consequently, the collected tritium is diluted in the comparatively much larger volume of scrubber water that is used. The liquid scrubber can be water or a solution of $\mathrm{NaCl}$ or $\mathrm{KCl}$ augmented with $\mathrm{NaOH}$ or $\mathrm{KOH}$.

This system is more appropriate for an industrial scale operation because (1) of its selectivity for $\mathrm{HCl}$, (2) it does not consume excess amounts of reagents, (3) it does not produce large amounts of copper bearing waste, and (4) it has the ability to recycle the chlorine gas back into the zirconium recycle process. To recycle chlorine to the zirconium processing step will require that chlorine gas first be dried; otherwise, the water vapor will convert a portion of the zirconium to non-volatile oxide forms that report to the waste systems. 


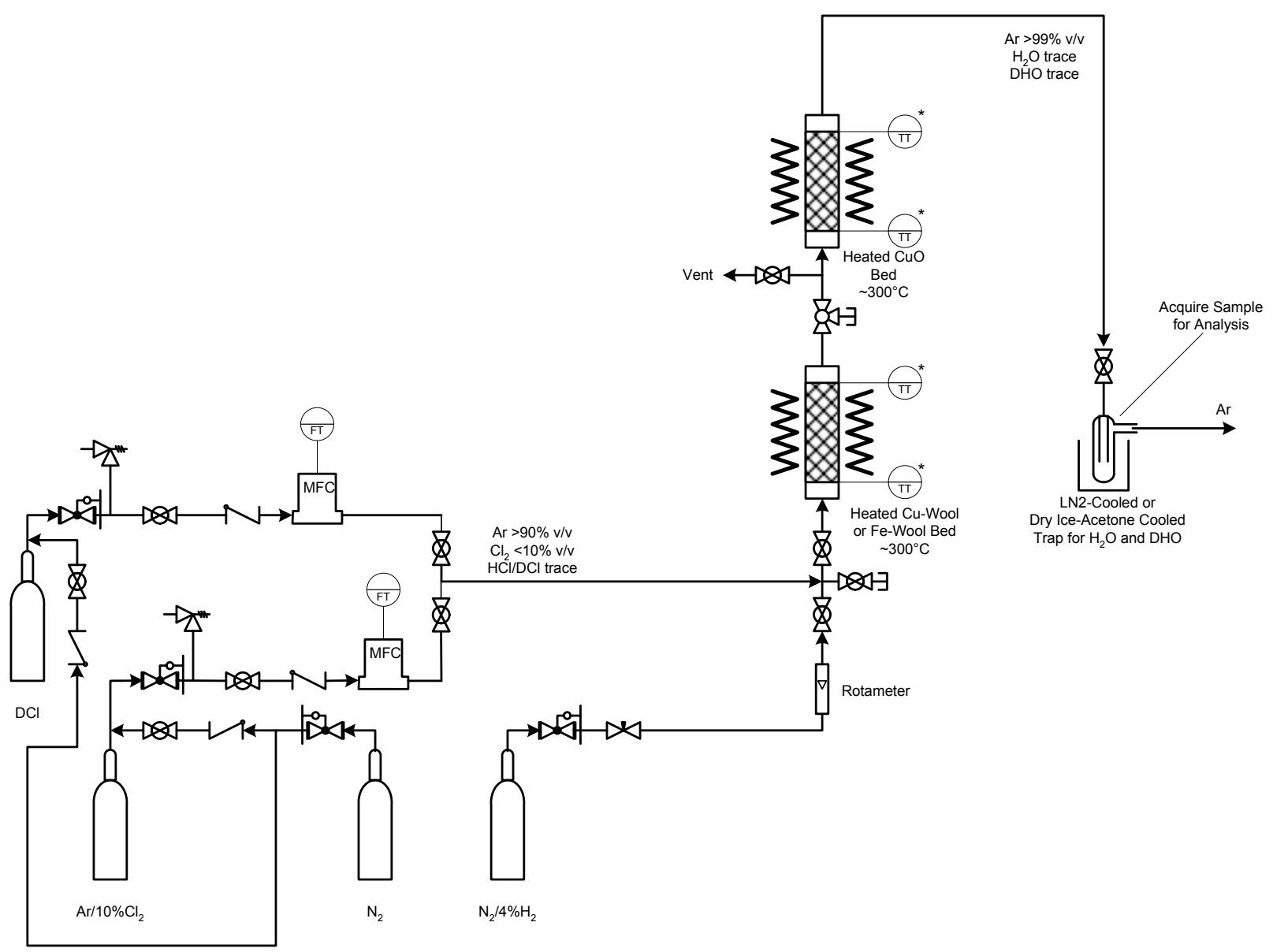

Figure 4. Conceptual process design for recovery of $\mathrm{HCl}$ from dilute off-gas streams by chemical conversion.

For the proof-of-principle experiments described here, the following simplifications were implemented:

1) $\mathrm{DCl}$ was used as a stand-in for all of the isotopically different $\mathrm{HCl}$ compounds, with a total concentration in the gas stream of $\sim 2 \% \mathrm{v} / \mathrm{v}$.

2) $\mathrm{SnCl}_{4}$ and $\mathrm{Cl}_{2}$ were not included in the prototypic stream.

3) A recirculating scrubber was not required due to the short duration of tests.

4) The scrubber was a liquid column scrubber with ceramic frit to disperse the gas as small bubbles.

5) Soda-lime neutralization was not required because $\mathrm{Cl}_{2}$ was not included in the prototypical gas stream. 


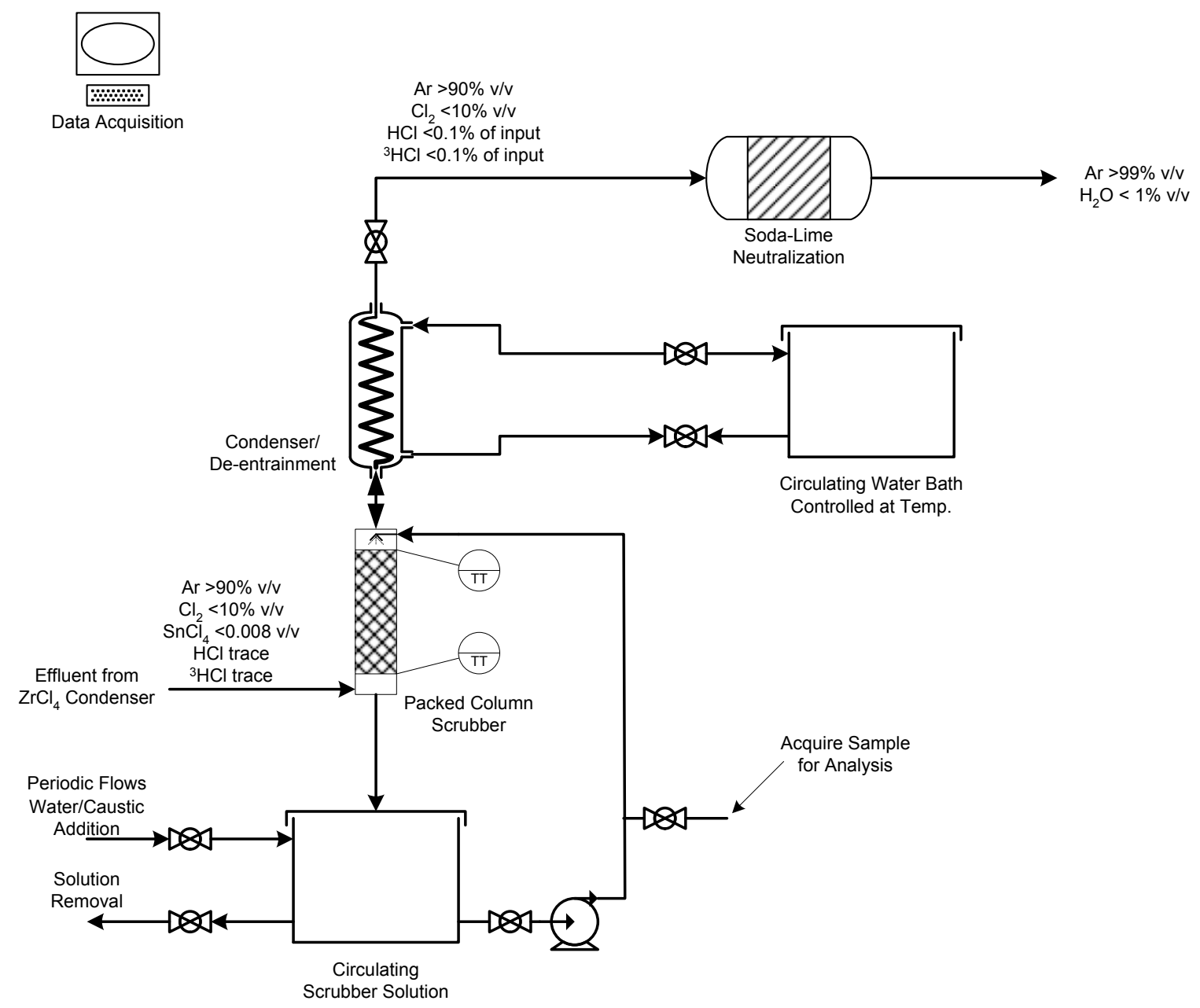

Figure 5. Conceptual process design for recovery of $\mathrm{HCl}$ from dilute off-gas streams by liquid scrubbing.

\section{MATERIALS AND METHODS}

The proof-of-principle experiments were conducted using these two proposed $\mathrm{HCl} /{ }^{3} \mathrm{H}$ recovery methods. Both were performed using a gas stream composed of $\sim 2 \% \mathrm{v} / \mathrm{v} \mathrm{DCl}$ with the balance being Ar. The DCl was procured from Sigma-Aldrich in a $450 \mathrm{~mL}$ gas cylinder $(99 \%$ atom $\% \mathrm{DCl})$. Due to the corrosive nature of $\mathrm{HCl}$ and chlorine, care was taken throughout the experiments to purge the regulator, tubing, and capture beds with inert gas following each run. Although the concentration of $\mathrm{HCl}$ in the zirconium recycle effluent is expected to be at trace levels, using a $\mathrm{DCl}$ concentration of $2 \% \mathrm{v} / \mathrm{v}$ simplifies the experimental design, and the concentration is still sufficiently low for these proof-of-principle demonstrations. Carrier gas was ultra-pure argon (Air Liquide) in both types of experiments

The aqueous solutions recovered in these experiments were sent to The University of Tennessee (UT) Stable Isotope Laboratory for analysis of the $\mathrm{D} / \mathrm{H}$ ratio within the samples. These measurements were performed on a Los Gatos Research DLT-100 Liquid Water Isotope Analyzer, which has an experimental range of $\mathrm{D} / \mathrm{H} 0.00008$ to 0.00016 . The UT Stable Isotope Laboratory routinely calibrates the analyzer with known standards. As a separate check, samples of water having natural abundance of ${ }^{2} \mathrm{H}$ were included along with samples collected from the experiments. 


\subsection{Demonstration of Chemical Conversion Process}

Two experimental tests of the chemical conversion process were performed. Both tests utilized steel wool (super-fine, Rhodes American) in the first sorbent bed to release deuterium from $\mathrm{DCl}$ as $\mathrm{D}_{2}$ (Equation 8), and the second sorbent bed contained copper oxide (Beantown Chemical $\mathrm{CuO}$ wire segments and Baker Analyzed ${ }^{\circledR}$ Reagent $\mathrm{CuO}$ wire) to convert the $\mathrm{D}_{2}$ to $\mathrm{D}_{2} \mathrm{O}$ as in Equation 6 . The experimental system is shown in Figure 6.

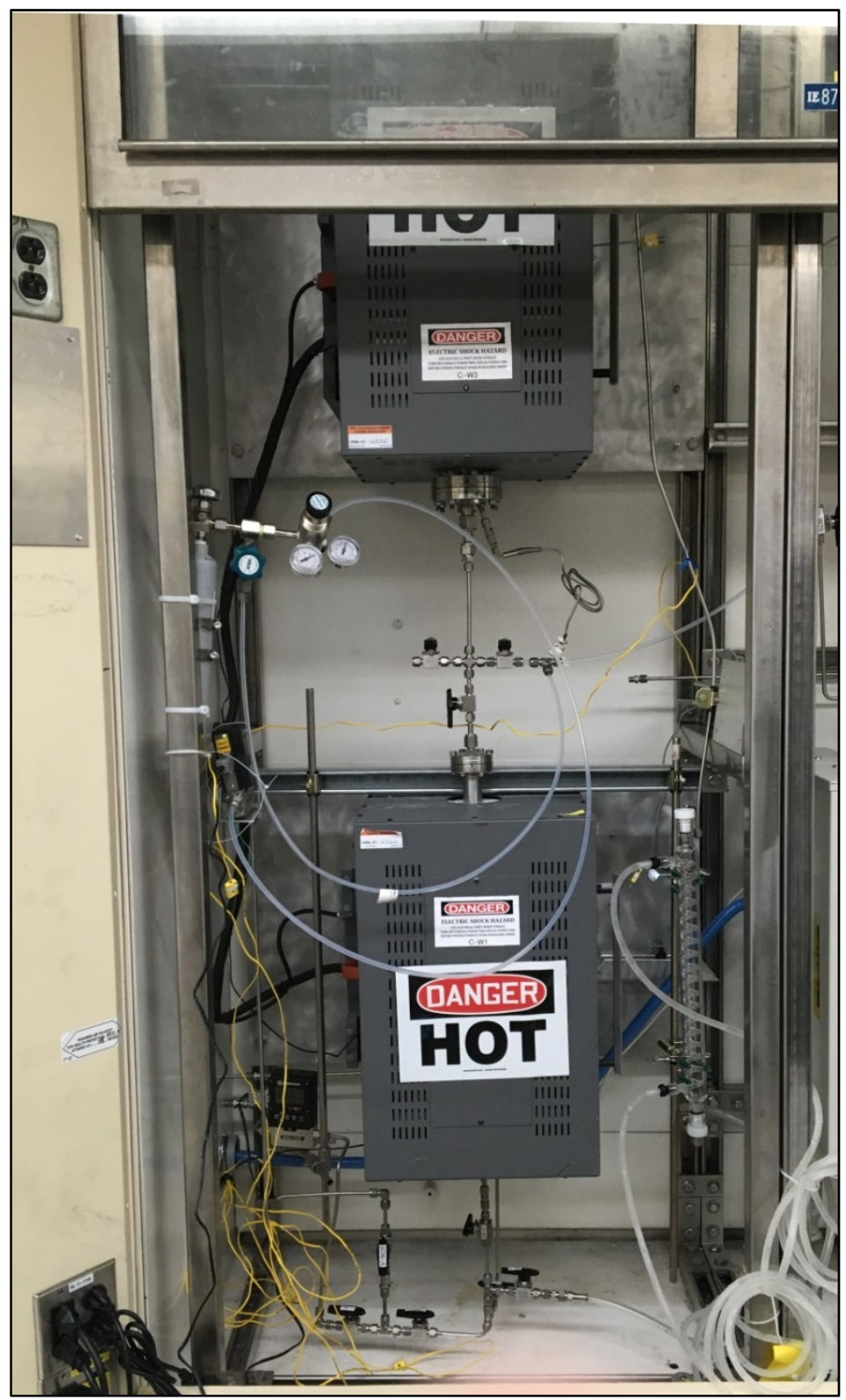

Figure 6. Experimental system for conversion approach to collecting deuterium as water.

Both tests held the iron wool bed (lower furnace) at $150{ }^{\circ} \mathrm{C}$; the $\mathrm{CuO}$ bed (upper furnace) was held at $250{ }^{\circ} \mathrm{C}$ for the first test and at $275^{\circ} \mathrm{C}$ for the second test. The first test ran for $4.0 \mathrm{~h}$ and the second for 
$\sim 6.4 \mathrm{~h}$. Upon the conclusion of each test, condensed liquid was observed within a cold finger contained in a dry ice/acetone bath $\left(-78^{\circ} \mathrm{C}\right)$. Assuming the chemical conversion was successful, this liquid will be $\mathrm{D}_{2} \mathrm{O}$. The entire trap was weighed empty prior to the test (tare) and after the test, while containing condensate, so the mass of condensate collected was easily determined. A few milliliters of distilled water, with naturally occurring levels of $\mathrm{D} / \mathrm{H}$, were used to rinse the inside of the cold finger and recover the small quantities of condensate; rinsing was completed after the trap warmed to room temperature. This resulted in some dilution of the sample, but dilution was nevertheless required to put the deuterium concentration into the range of the analytical instrument. Samples of this water were analyzed for D/H ratio.

The liquid recovered from the second test had a yellow tint to it, as shown in Figure 7. The cause of this was unknown, but it could be due to a number of factors such as incomplete conversion (condensation of $\mathrm{DCl}$ rather than $\mathrm{D}_{2} \mathrm{O}$ ), corrosion in the piping system, or impurities in the iron wool reagent. The $\mathrm{pH}$ of the condensate from the second test was equal to 1 . This condensate was recovered by the same dilution method described in the first test, and a sample was analyzed for $\mathrm{D} / \mathrm{H}$ ratio. A sample of the condensate also was sent for inductively coupled plasma mass spectrometry (ICP-MS) analysis to quantify any potential impurities, and these results are pending. After the conclusion of this run, corrosion was observed on some fittings of the DCl regulator, and the regulator was replaced prior to the experiments described in Section 4.2.

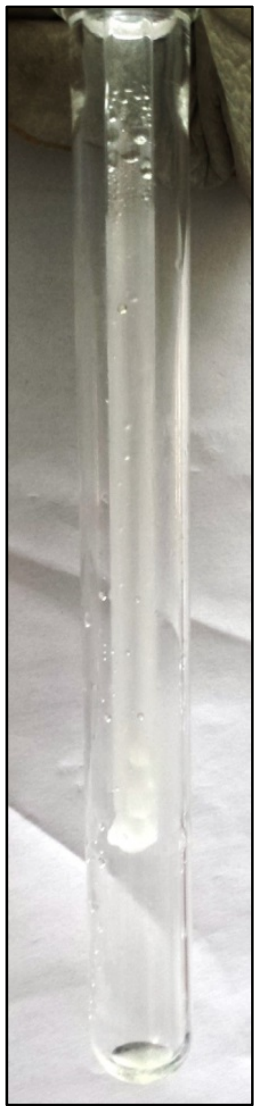

Figure 7. Condensate recovered from second chemical conversion test. 
Table 6 summarizes the mass balance of deuterium, the amount of condensate collected, and the calculated and measured $\mathrm{D} / \mathrm{H}$ ratios. The mass of condensate collected from test 1 and test 2 , presumably $\mathrm{D}_{2} \mathrm{O}$, was $28.4 \%$ and $66.2 \%$ (respectively) of the amount expected from an ideal system. This would seem to indicate either poor conversion of $\mathrm{DCl}$ to $\mathrm{D}_{2} \mathrm{O}$ or losses of $\mathrm{D}_{2} \mathrm{O}$ from the cold trap. Based on the very low concentration of water vapor in the stream leaving the conversion furnaces, and the visual observation of the cold trap, it seems possible that some of the water escaped the cold finger as very fine snow. The measured $\mathrm{D} / \mathrm{H}$ ratios were considerably smaller than those estimated based on quantitative recovery of the deuterium. Calculating the $\mathrm{D} / \mathrm{H}$ ratios based on the actual mass of condensate collected resulted in $\mathrm{D} / \mathrm{H}$ ratios 1.6 to 2.6 times greater than those measured by analysis. This could be caused if the rinse water did not contact all surfaces on which $\mathrm{D}_{2} \mathrm{O}$ was located: Visually most of the inside surface of the cold trap was fogged with condensed sample, so incomplete contact with the rinse water is one explanation. A deuterium balance based on the quantity delivered as $\mathrm{DCl}$ and the deuterium analysis in the collected water indicates only $10.9 \%$ to $44.7 \%$ recovery.

Table 6. Analysis of condensate samples from conversion-cold trapping tests

\begin{tabular}{|c|c|c|}
\hline Run \# & 1 & 2 \\
\hline Runtime (min) & 240 & 387 \\
\hline Ar flowrate (sccm) & 200.0 & 200.0 \\
\hline $\mathrm{DCl}$ flowrate $(\mathrm{sccm})$ & 4.0 & 4.0 \\
\hline $\mathrm{DCl}$ delivered $(\mathrm{g})$ & 1.489 & 2.401 \\
\hline $\mathrm{D}_{2} \mathrm{O}$ equivalent delivered $(\mathrm{g})^{a}$ & 0.398 & 0.642 \\
\hline Condensate recovered $(\mathrm{g})^{b}$ & 0.113 & 0.425 \\
\hline Deuterium recovered $(\%)^{c}$ & 28.4 & 66.2 \\
\hline Rinse water added $(\mathrm{g})^{d}$ & 6.703 & 6.834 \\
\hline $\mathrm{D} / \mathrm{H}$, calculated $^{e}$ & 0.0535 & 0.0846 \\
\hline $\mathrm{D} / \mathrm{H}$, based on recovered mass ${ }^{f}$ & 0.01532 & 0.05610 \\
\hline $\mathrm{D} / \mathrm{H}$, instrumental analysis ${ }^{g}$ & 0.005862 & 0.035674 \\
\hline Deuterium recovered $(\%)^{h}$ & 10.9 & 44.7 \\
\hline
\end{tabular}

${ }^{a}$ Based on complete conversion of $\mathrm{DCl}$ to metal chloride and water.

${ }^{b}$ Condensate collected in cold finger is assumed to be $\mathrm{D}_{2} \mathrm{O}$.

${ }^{c}$ As determined by mass.

${ }^{d}$ The amount of natural water used to flush the condensate from the cold finger.

${ }^{e}$ This is the ratio calculated to be in the mixed condensate and rinse if $\mathrm{D}_{2} \mathrm{O}$ were quantitatively converted from $\mathrm{DCl}$ and quantitatively recovered.

${ }^{f}$ This is the ratio calculated assuming the actual mass of condensate recovered was $\mathrm{D}_{2} \mathrm{O}$.

${ }^{g}$ This is the ratio found in the mixed condensate and rinse by sample analysis.

${ }^{h}$ As determined by $\mathrm{D} / \mathrm{H}$ analysis. 


\subsection{Demonstration of Liquid Scrubbing Process}

Two tests of the liquid scrubbing process were completed. The gas supply system delivered gas directly to the scrubber shown in Figure 8. The simulated zirconium recycle off-gas stream passed through $0.1 \mathrm{M}$ $\mathrm{NaOH}$ (Aqua Solutions, Inc.) for $4.1 \mathrm{~h}$ in the first test, and the gas stream passed through $1.0 \mathrm{M} \mathrm{NaOH}$ for $5.0 \mathrm{~h}$ in the second test. The liquid was recovered for analysis of the $\mathrm{D} / \mathrm{H}$ ratio. Analysis of samples from the first test was completed. Analysis of samples from the second test is underway and will be reported in a subsequent document.

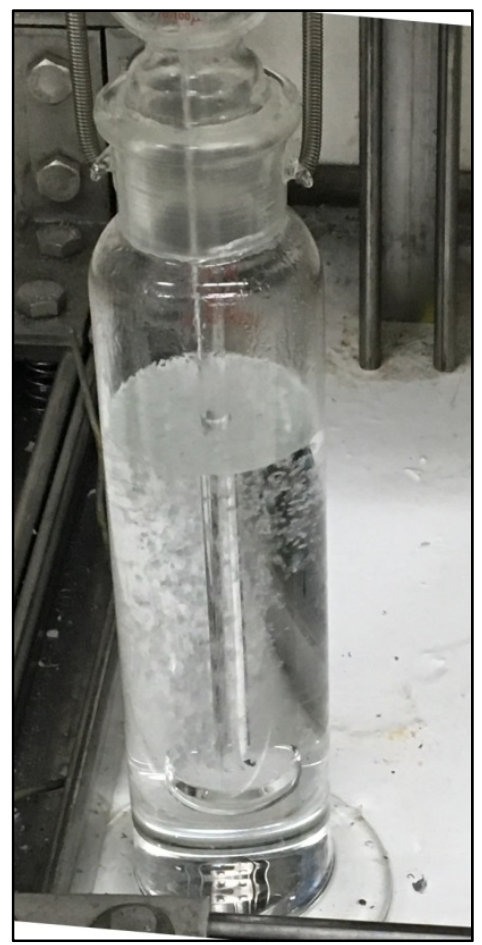

Figure 8. Caustic scrubber to capture DCl from the synthetic off-gas stream.

In the first scrubber test $\sim 502 \mathrm{~mL}$ of $0.1 \mathrm{M} \mathrm{NaOH}$ solution was used to capture the $\mathrm{DCl}$, converting it to $\mathrm{NaCl}$ and $\mathrm{HDO}$. Gas flow rates were the same as in previous tests, specifically $200 \mathrm{sccm}$ Ar and $4.0 \mathrm{sccm}$ $\mathrm{DCl}$. Assuming the $\mathrm{DCl}$ was quantitatively scrubbed from the gas stream, the calculated $\mathrm{D} / \mathrm{H}$ ratio for the scrubber solution upon test conclusion would be 0.00163. Analysis of the sample gave a value of $\mathrm{D} / \mathrm{H}=0.0005864$, indicating only $59.0 \%$ recovery of the deuterium. Possible explanations for the low recovery include losses due to insufficient residence time in the scrubber to allow transfer of $\mathrm{DCl}$ from the gas stream to the liquid, and losses of $\mathrm{DCl}$ to corrosion of the piping system (including the new gas regulator). The corrosion observed in the first regulator during the chemical conversion tests casts uncertainty in the mass of deuterium that was delivered to both experimental systems during testing, as any corrosion in the original or replacement regulator could significantly alter the feed stream.

In a third test of the caustic scrubbing system, the primary scrubber effluent was passed through a second scrubber. This approach will allow experimental determination of the scrubbing efficiency of the primary scrubber. 1.0 M NaOH was used as the scrubber solution for both scrubbers. After exposure of the scrubbers to the feed gas for $5 \mathrm{~h}$, samples of the final solutions were taken for analysis of deuterium 
content at the University of Tennessee and for chlorine content in ORNL laboratories. These results are pending.

\section{DISCUSSION}

Both methods to recover the deuterium from dilute streams of $\mathrm{DCl}$ were completed. Mass balances on the conversion cold-trapping system were poor and thought to be caused by losses of the water in the form of frozen aerosol from the cold trap or due to corrosion of the $\mathrm{DCl}$ regulator. There is also a potential loss of chlorine to stainless steel piping components (with evolution of hydrogen), despite efforts to mitigate this through inert gas purges between each experimental test. Losses in the form of molecular hydrogen impact the scrubber approach to trapping tritium.

The amount of Zircaloy cladding that can be used in the upcoming hot cell demonstration determines the amount of ${ }^{3} \mathrm{H}$ that may be recovered. Although the conversion method collects the HDO or $\mathrm{D}_{2} \mathrm{O}$ in concentrated form, which would be advantageous for collecting HTO for radiochemical analysis, the need to operate two furnaces and a very low temperature cold trap proved cumbersome. The approach using the caustic scrubber collected the $\mathrm{HDO}$ or $\mathrm{D}_{2} \mathrm{O}$ in a very dilute form, but it was much easier to implement and operate. In addition, the scrubber required little in the way of controls (e.g., temperature controllers) and floor space. If the radiochemical analysis is sufficiently accurate to close the material balance on the HTO, then the caustic approach is preferred.

The analysis results pending from the third caustic scrubbing test will provide information not only relevant to the specific test conducted, but will also aid in interpretation of the results of the off-gas treatment that will be performed in the hot cell during the FY16-FY17 demonstration of the zirconium recycle process. By knowing the efficiency of the caustic scrubber and by obtaining measureable tritium in the scrubber solution upon conclusion of cladding chlorination, a reliable estimate of the amount of tritium present within the cladding used in the hot-cell demonstration can be determined.

\subsection{A System to Support Hot-Cell Zirconium Processing Operations}

Both systems tested using non-radioactive simulant streams are capable of collecting about $2 / 3$ of the deuterium from an argon stream having a low concentration of $\mathrm{DCl}$. Corrosion of the stainless steel piping systems could have consumed part of the $\mathrm{DCl}$ in both types of systems, leading to the low recovery in the scrubber system. Observed fractional recoveries do not distinguish between the approaches.

For hot-cell operations, a scrubber system was selected to implement recovery of tritium from the off-gas of the upcoming zirconium recovery experiment. This selection was strongly driven by the simple hardware required for implementation and because it requires minimal electrical services. The selected materials of construction include glass vessels, polymeric fittings and valves, and polymeric seals. The main vessel has a $50 \mathrm{~mm}$ inside diameter, and the glass dispersion frit will be submerges about $30 \mathrm{~cm}$ (12 in.) below the liquid surface; about twice as much as the system tested in the proof-of-principle experiments. A schematic of this system is shown in Fig. 9, with the assembled system shown in Fig. 10. This system will be cold tested with a $\mathrm{Cl}_{2} / \mathrm{Ar}$ blend to ensure that there is no plug formation at the gasliquid interface within the glass dispersion frit. If plugging becomes a concern, a larger mesh frit can be substituted. Additionally, if liquid condensate is expected between the caustic scrubber and the soda lime bed, a knockout pot will be installed between the two reactor bodies. The system is expected to be installed in the hot cell in early FY17. 


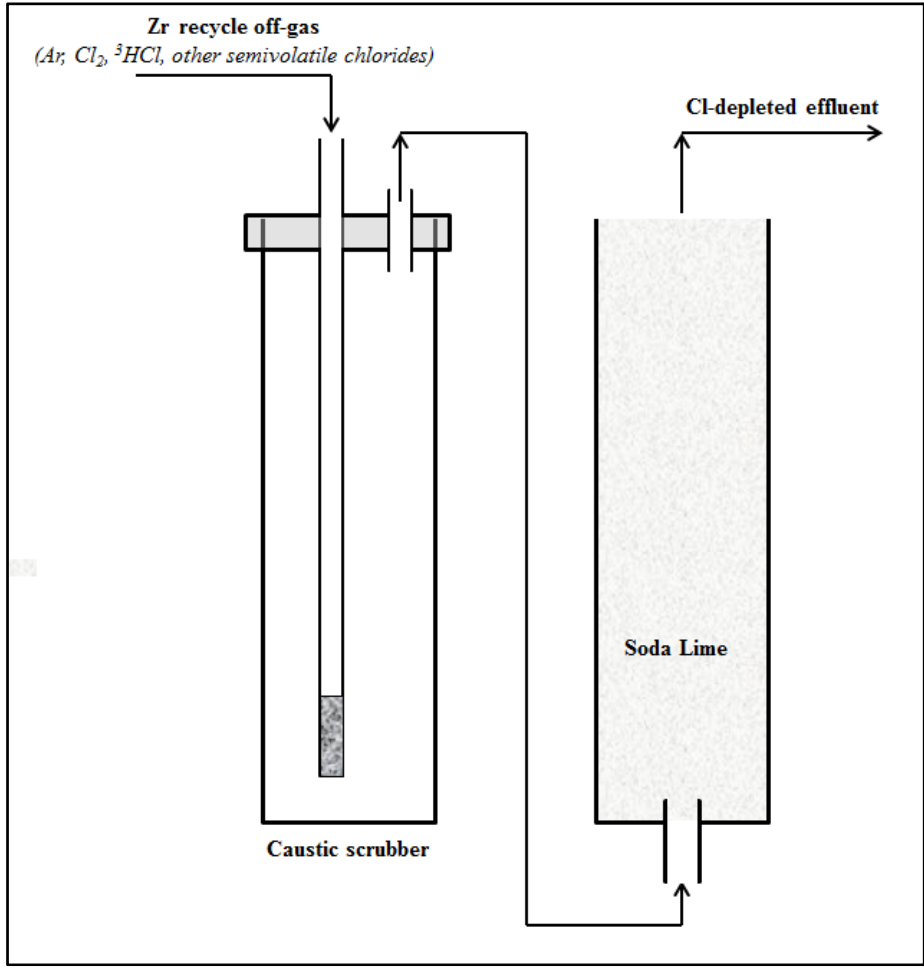

Figure 9: Schematic of off-gas treatment system for use in zirconium recycle hot-cell demonstration

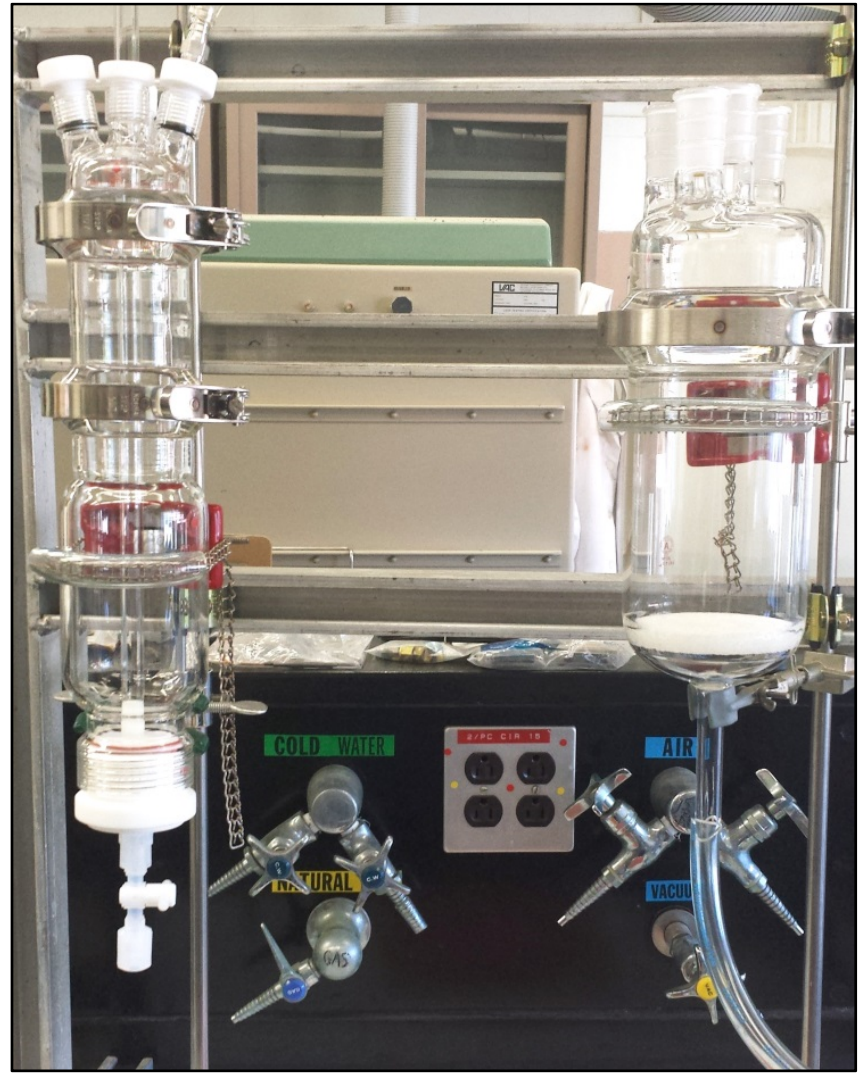

Figure 10: Assembled scrubber system 


\section{REFERENCES}

1. E. D. Collins, B. B. Spencer, G. D. DelCul, R. R. Brunson, J. A. Johnson, Roadmap for Zirconium Recovery/Recycle Process Development, ORNL/LTR-2012/609, also FCRD-SWF-2013-000074, UT-Battelle, LLC, Oak Ridge National Laboratory, December 2012.

2. S. M. Robinson, M. R. Chattin, J. M. Giaquinto, and R. T. Jubin, Evaluation of Tritium Content and Release from Pressurized Water Reactor Fuel Cladding, ORNL/SPR-2015/425, also FCRDMRWFD-2015-000617, UT-Battelle, LLC, Oak Ridge National Laboratory, September 2015.

3. R. C. Weast, Ed., CRC Handbook of Chemistry and Physics, $70^{\text {th }}$ ed., CRC Press, Inc., Boca Raton, Florida, 1989.

4. Croff, A. G. and C. W. Alexander. 1980. Decay Characteristics of Once-Through LWR and LMFBR Spent Fuels, High-Level Wastes, and Fuel-Assembly Structural Material Wastes. ORNL/TM-7431, Union Carbide Corp., Oak Ridge National Laboratory, November (Applied Technology).

5. Cochran, R. G. and N. Tsoulfanidis. 1999. The Nuclear Fuel Cycle: Analysis and Management, 2nd ed. American Nuclear Society, La Grange Park, Ill.

6. J. C. Gehin and R. T. Primm, III. 1997. Light Water Reactor Mixed Oxide Benchmark I, American Nuclear Society, La Grange Park, Ill.

7. J. Eng and S. H. J. Greenwood, "Chlorine Separation Process," US Patent 3,001,607, Sept. 26, 1961.

8. Physical properties from http://webbook.nist.gov, accessed October 20, 2015.

9. P. Schmittinger, Chlorine: Principles and Industrial Practice, $1^{\text {st }}$ ed., Wiley-VCH, Weinheim, Federal Republic of Germany, 2000.

10. Kirk-Othmer Encyclopedia of Chemical Technology, John Wiley \& Sons, Inc., published on-line 4 December 2000.

11. A. H. Hardin and N. Sheppard, "Infrared spectra of $\mathrm{HCl}$ adsorbed on high-area alkali-metal halides: Dependence of the effective surface ionicities on the ionic radius ratio, J. Chem. Soc., Dalton Trans., pp. 1289-1292, 1999.

12. EMD Millipore, "Molecular Sieves: Drying Application by Type," https://www.emdmillipore.com, October 22, 2015.

13. Semco Inc., "Importance of the 3A Molecular Sieve Desiccant Coated Total Energy Recovery Wheel to the HVAC Indoor Air Quality (IAQ) Market," Rev. 3, www.semcoinc.com, October 20, 2015.

14. Molecular Products Ltd., "An Overview of Large and Small Scale Adsorption and Catalytic Gas Processing," version 2, 5/08/09.

15. W. G. Berl, Ed., Physical Methods in Chemical Analysis: Vol. IV, Academic Press, New York, 1961. 